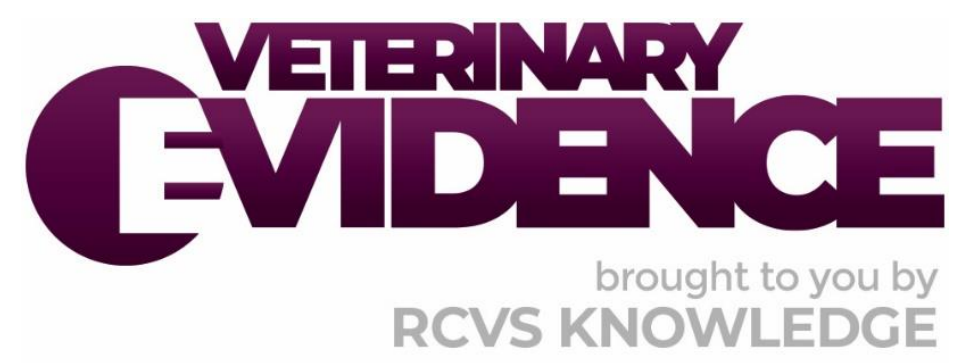

\title{
Age at first calving in dairy cows: which months do you aim for to maximise productivity?
}

A Knowledge Summary by

Mike Steele BSc(Hons), BVSc, MRCVS ${ }^{1^{*}}$

\footnotetext{
${ }^{1}$ Inspire Cattle Solutions, 10 Granborough Road, Winslow, Buckinghamshire, MK18 3BP

*Corresponding Author (mike@dairyconsulting.vet)
}

ISSN: 2396-9776

Published: 19 Mar 2020

in: Vol 5, Issue 1

DOI: 10.18849/VE.V5I1.248

Reviewed by: Alastair Hayton (BVM\&S, DCHP, MRCVS) and

Claire Weeks (BSc) 


\section{KNOWLEDGE SUMMARY}

\section{PICO question}

In dairy cattle, which months should producers target age at first calving in order to maximise milk yield, minimize risk of non-voluntary culling and optimize fertility?

\section{Clinical bottom line}

\section{Category of research question}

Risk

\section{The number and type of study designs reviewed}

Seventeen papers were critically reviewed: 15 sets of case series, one review of case series and cohort studies and one randomised control trial, summarising over 2.4 million individual cow records

\section{Strength of evidence}

\section{Strong}

\section{Outcomes reported}

An optimum range of age at first calving (AFC) on dairy farms appears to be 22-25 months inclusive. Lower or higher than this figure can bring lower first lactation 305 day and lifetime milk yields, lower fertility and lower chances of surviving to a second lactation. Achieving an AFC of 22-25 months can bring the highest economic return to dairies

\section{Conclusion}

Age at first calving is a useful and key performance parameter to measure in dairy cattle. Achieving a range of 22-25 months at first calving can help to optimise both long term milk yield, fertility and longevity within the herd

\section{How to apply this evidence in practice}

The application of evidence into practice should take into account multiple factors, not limited to: individual clinical expertise, patient's circumstances and owners' values, country, location or clinic where you work, the individual case in front of you, the availability of therapies and resources.

Knowledge Summaries are a resource to help reinforce or inform decision making. They do not override the responsibility or judgement of the practitioner to do what is best for the animal in their care.

\section{Clinical Scenario}

The age at which a cow calves for the first time is a key indicator of the quality of youngstock management. Rate of growth in the heifer until she is inseminated, conceives and subsequently calves 9 months later can be affected by many factors. Nutrition quality and availability, disease risk (including parasitism), breed and insemination practices being only some of these influencing factors (Adamczyk, 2017; Bond, 2015; Davis Rincker, 2011 and MacDonald, 2005). A recent review of UK dairy herd data showed that the average (mean) age at first calving (AFC) was 29 months (median 28 months) (Eastham, 2018). This seemed significantly greater than the target of 22-24 months that is often quoted in press. Although there have been publications to summarise the performance effects of varying the AFC, few have concentrated on yield and reproduction together, in the same article and included data from more than one country. 


\section{The evidence}

There are 17 articles recorded in this Knowledge Summary. They reflect a geographical range representative of Holstein-Friesian (Bos taurus) dairy cows in Europe, Asia and North America. There is one review of case series articles, including 125 referenced articles from 1979-2014. There is one randomised control trial, focusing on growth rates and AFC. The other 15 papers are case series, including data collected from dairy software on farms mostly involving dairy herd improvement (DHI) schemes. These include data from at least 2,645,158 cow records (one paper from Iran does not publish the number of cows in the dataset but describes the data as originating from 12 large farms and defines large farms in Iran to include roughly 7,000 cows per farm). Correlations in data are largely indicated by linear regression and covariance analysis and the main findings reported have been stated when either significant or no significant difference was observed at $p$-values of $<0.05$.

\section{Summary of the evidence}

Of the 17 articles discussed in this Knowledge Summary, the reported range of AFC is from 18 months old to 42 months old. The mean average AFC reported in each study differs by country, with Iran and USA at 25.5 months and UK at 29 months (Ettema J.F. 2004) (Elahi Torshizi M. 2016). Papers from other European countries do not report mean average but describe a commonly recorded AFC on farm, to be between 26 and 30 months (Krpalkova, 2014 and Pirlo, 2011). As mentioned in the methodology section, this Knowledge Summary has reflected the PICO and is not focused on the influencing factors of AFC but it is worth noting that major inputs to AFC include diet (intensive rearing or less intensive, both preweaning and post-weaning) and insemination procedures. Obviously, AFC reflects the gestation length of cattle (9 months) and insemination depends on animals reaching puberty and cycling healthy, viable ova. Wathes (2014) states that the onset of puberty can occur from 10 months and can be brought forwards by intensive rearing management and diets (Chester-Jones, 2017). Chester-Jones (2017) also notes that to maximise the occurrence of healthy ova, at least three cycles should be allowed before inseminaton should be practised.

\section{Optimum range of AFC}

The optimum range of AFC varies according to paper, outcome studied and geographical region but a consensus can be seen in overlapping months:

- 18-23 months (Banos, 2007): This range is inclusive of all data from 18-23 months and not considering data from each month separately

- 22 months (Eastham, 2018)

- 5-23.5 months (Changee, 2013)

- 22-24 months (Pirlo, 2011 and Nilforooshan, 2004)

- 22-26 months (Elahi Torshizi, 2016)

- 23-25 months (Ettema, 2004)

- $\quad<24$ months (Adamczyk, 2017)

- 5 months (Krpalkova, 2014)

- 25-26 months (Storli, 2017)

In summary, most papers agree that from their observations that the optimum AFC falls between 22-25 months inclusive. Beyond this in either direction, there appear to be detrimental consequences on one or more of the outcome effects reported below.

The effects of varying AFC have fallen mainly into 4 categories:

1. Milk Yield (first lactation 305 day yield; lifetime yield)

2. Fertility (first service conception rate; calving interval, days open, inseminations per pregnancy)

3. Longevity (survival to second calving and overall survival length)

4. Economic Return (return on rearing cost; loss/month compared to other AFC groups)

Consequently, each will be reported as a separate effect below: 


\section{Milk Yield}

Milk yield (MY) has been measured as the volume of milk harvested from the cow in the 305 day lactation following her first calving (taken by addition of test-day results, daily milk weights or predicted 305 day yield in papers where yield was recorded over less than 305 days). Prediction of 305 day milk equivalent is a common parameter from dairy software recording systems that use equations linked to prediction of the lactation curve. Cows at certain days in milk (DIM) can have known monthly test day results to base a prediction figure from and calculate their predicted yield to the end of that lactation. Another parameter reported has been in MY from the cow over her total productive lifetime (either in total milk volume or average daily yield).

In terms of volume, milk losses and gains can be regarded from the perspective of pre-22 months; 22-25 months and post 25 months AFC. At an AFC of less than 22 months, 590-800 kg losses in the first 305 day lactation have been reported by (Elahi Torshizi, 2016) and (Pirlo, 2011). Ettema (2004) included pre-23 months in his study and reports a $320 \mathrm{~kg}$ loss in the first lactation: the lower volume lost is most likely because the cows at 22-23 months were included in the calculation. Only one study reports higher yields in 18-23 months, quoting 4.5\% more milk from the first 305 day lactation (Banos, 2007). Cows with an AFC of greater than 25 months are also reported to have lower milk yields. Elahi Torshizi (2016) and Pirlo (2011) report a 170-600 kg loss in milk above 26 months. Berry (2009) reported that first lactation 305 day yield decreases by $55.5 \mathrm{~kg}$ less per month, increasing from 22 months AFC to 38 months. Cows calving between 22-25 months have been found to produce $2.1-2.4 \mathrm{~kg} /$ day more milk than their counterparts calving outside this window of time (Storli, 2017 and Eastham, 2018).

In summary, there appear to be lower milk yields of between 170 and $600 \mathrm{~kg}$ in the first lactation in cows with low AFCs (18-21 months) and 590-800 kg less yield in cows with high AFCs (>26 months).

\section{Fertility}

There is less clarity over fertility effects of varying age at first calving, mainly due to the parameters that researchers have measured on performance of reproduction. This is discussed in the appraisal section below. First service conception rate was reported by Ettema (2004) to be highest in AFC of $<23$, then $23-25$, then $>25$ months $(75 \%, 64 \%, 45 \%)$. Conversely, days open and calving interval have been reported as improving in older AFC groups (>26 months) compared to AFCs of $<26$ months (Eastham, 2018) and (Krpalkova, 2014). Banos, (2007) suggested that fertility would be compromised in younger AFC cattle by reporting $7 \%$ more inseminations per pregnancy and 7.5\% higher return rate in AFC between 18-23 months.

In summary, although more papers suggest higher fertility rates in older AFC cattle, one key paper reflects that aiming for lower AFC does not compromise first service conception rate targets (Ettema, 2004).

Longevity

There has been no significant, direct effect of AFC on the survival length of cattle reported Nilforooshan (2004 and Wathes (2014). However, it must be noted that longevity of cattle is strongly linked to productivity and less productive cattle are more likely to be culled. Therefore, links can be made between AFC and survivability: Eastham (2018) suggests that cows calving between 22-26 months old are more likely to survive to calve a second time but this is not a reflection of the AFC itself but rather the management of transition and early lactation as a whole.

\section{Profitability}

Whether or not AFC affects the profitability of a dairy is a difficult and highly variable parameter to calculate, as so many factors in the management of both heifer rearing and lactation affect dairy profit. However, five of the reviewed papers have attempted to associate AFC with profitability. The longer it takes for a heifer to enter the milking herd, the more feed and management costs are involved in rearing her. Ettema (2004) observed that an AFC of 22-24 months was US\$98-138 preferable per heifer than other AFCs. Pirlo (2011) calculated that an AFC of 22-26 months improved income per heifer by US\$24-41 over other AFCs and Changee (2013) reported that an AFC of 22.5 months gave up to US\$727 higher lifetime returns compared to an AFC of 32 months. Krpalkova (2014) suggests that between 24-26 months of AFC returns the highest 
profitability but does not state the amount: the statement is based on higher milk returns and fertility parameters. Wathes (2014) simply reviews the above papers.

In summary, it seems that an AFC of between 22-26 months produces the highest returns compared to lower or higher AFCs.

\section{Acronyms}

ADWG = average daily weight gain

$\mathrm{AFC}=$ age at first calving

$\mathrm{BCS}=$ body condition score

$\mathrm{BW}=$ body weight

$\mathrm{CP}=$ crude protein

$\mathrm{ECM}=$ energy corrected milk

$\mathrm{DHI}=$ dairy herd improvement

DIM = days in milk

$\mathrm{DM}=$ dry matter

HOL/FR = Holstein-Friesian

$\mathrm{MY}=$ milk yield

$\mathrm{SCC}=$ somatic cell count

$\mathrm{SCS}=$ somatic cell score

$\mathrm{SD}=$ standard deviation

\begin{tabular}{|c|c|}
\hline \multicolumn{2}{|l|}{ Eastham et al. (2018) United Kingdom } \\
\hline Population: & Primiparous, mainly HOL/FR dairy cows \\
\hline Sample size: & $\begin{array}{l}396,534 \text { cows from 6,985 herds in UK. National Milk Record } \\
\text { database data from 2006-2008 }\end{array}$ \\
\hline Intervention details: & Varying AFC and production parameters \\
\hline Study design: & Case series \\
\hline Outcome studied: & $\begin{array}{l}\text { First lactation MY } \\
\text { Lifetime MY } \\
\text { First lactation milk fat and protein yield } \\
\text { First lactation SCC } \\
\text { Likelihood to calve a second time }\end{array}$ \\
\hline $\begin{array}{l}\text { Main findings: } \\
\text { (relevant to PICO question): }\end{array}$ & $\begin{array}{l}\text { - Mean AFC was } 29 \text { months and median } 28 \text { months. Range } \\
18-42 \text { months } \\
\text { - } 3 \% \text { calved }<24 \text { months; } 40.9 \% \text { calved } \geq 30 \text { months } \\
\text { - } \quad \text { Lowest predicted first } 305 \text { day yield was }<21 \text { months AFC } \\
\text { (6,617 kg) } \\
\text { - Highest predicted first } 305 \text { day yield was }>34 \text { months AFC } \\
\text { ( } 7,774 \mathrm{~kg}) \\
\text { - Animals with AFC of } 21 \text { months had an SCC of } 72,765 \text { and } \\
\text { those with an AFC of } 36 \text { months had an SCC of } 86,648 \\
\text { - Animals with an AFC of } 41 \text { months had a modelled increase } \\
\text { in calving interval ( } 416 \text { days) compared with AFC of } 23 \\
\text { months ( } 401 \text { days) } \\
\text { - Animals with an AFC of } 22 \text { months had a mean daily lifetime } \\
\text { yield of } 15.24 \mathrm{~kg} \text { and those of } 36 \text { months had a mean daily } \\
\text { lifetime yield of } 12.83 \mathrm{~kg}\end{array}$ \\
\hline
\end{tabular}




\begin{tabular}{|c|c|}
\hline & $\begin{array}{l}\text { Predicted probability of calving for a second time was much } \\
\text { greater in animals with an AFC of 21-25 months (0.817- } \\
0.837) \text { compared with those greater than } 30 \text { months (0.649- } \\
0.782)\end{array}$ \\
\hline Limitations: & $\begin{array}{l}\text { Data is historical compared to publishing date. } \\
\text { Calving interval is dependent on pregnancy results and is a } \\
\text { comparatively historical evaluation of reproductive performance. It } \\
\text { is skewed by animals with very long days open or cull cows. }\end{array}$ \\
\hline
\end{tabular}

\begin{tabular}{|c|c|}
\hline \multicolumn{2}{|l|}{ Storli et al. (2017) Norway } \\
\hline Population: & $\begin{array}{l}\text { Norwegian Red dairy cow data from National Norwegian Herd } \\
\text { Records 2010-2012 }\end{array}$ \\
\hline Sample size: & $\begin{array}{l}350 \text { cows after exclusions to investigate the outcomes. Only first } \\
\text { lactation animals with single calves and within at least } 275 \text { and } 575 \\
\text { days of calving were included. }\end{array}$ \\
\hline Intervention details: & Growth rate, variance in AFC and first lactation yield \\
\hline Study design: & Case series \\
\hline Outcome studied: & Heart girth measurement, AFC and test-day MY from 0-305 DIM \\
\hline $\begin{array}{l}\text { Main findings: } \\
\text { (relevant to PICO question): }\end{array}$ & $\begin{array}{l}\text { - An optimal ADWG of } 0.830 \mathrm{~kg} / \text { day is associated with the } \\
\text { best first lactation yields } \\
\text { - First lactation yield is improved by } 2.5 \text { and } 2.1 \mathrm{~kg} / \text { day } \\
\text { respectively at AFC of } 25 \text { and } 26 \text { months compared with } 23 \\
\text { or less or greater than } 26 \text { months }\end{array}$ \\
\hline Limitations: & $\begin{array}{l}\text { Many animals were excluded from the original dataset (started with } \\
3,110) \text {. } \\
\text { Breed is not representative of most dairy herds globally. } \\
\text { As sample population decreases, the chances of other herd factors } \\
\text { influencing the AFC and yield as well as just growth are increased } \\
\text { (such as season of calving, heat stress, etc.). }\end{array}$ \\
\hline
\end{tabular}

\begin{tabular}{|r|l|}
\hline Chester-Jones et al. (2017) United States of America \\
\hline Population: & Holstein dairy cows \\
\hline Sample size: & 2,880 Holstein cows from three commercial dairy farms \\
\hline Intervention details: & $\begin{array}{l}\text { Starter intake, protein intake, milk replacer intake and birth season } \\
\text { of calves to } 195 \text { days old and AFC }\end{array}$ \\
\hline Study design: & Case series \\
\hline Outcome studied: & First lactation 305 day yield \\
\hline Main findings: & $\begin{array}{l}\text { Mean AFC was } 23.5 \text { months (46 days SD) but had no } \\
\text { (relevant to PICO question): }\end{array}$ \\
& $\begin{array}{l}\text { - Mean first lactation } 305 \text { day yield was } 10,959 \mathrm{~kg} \\
\text { - Mean ADWG was } 0.62 \mathrm{~kg} / \text { day at } 8 \text { weeks old }\end{array}$ \\
\hline
\end{tabular}




\begin{tabular}{|l|l|}
\hline - & $\begin{array}{l}\text { Every } 1 \mathrm{~kg} \text { of } 6 \text { week ADWG was associated with } 544 \mathrm{~kg} \\
\text { more first-lactation } 305 \text { day milk and every } 1 \mathrm{~kg} \text { of } 8 \text { week } \\
\text { ADWG yielded } 579 \mathrm{~kg} \text { more first-lactation } 305 \text { day milk but } \\
\text { there was great variation around the mean, so BW was } \\
\text { more associated with first lactation yield than ADWG. This is } \\
\text { true, due to BW being more related to birth weight and this } \\
\text { is strongly correlated to first lactation yield } \\
\text { - Starter pellet intake had a significant effect on first lactation } \\
\text { yields, with each } 1 \text { kg increase in intake resulting in } 8.21 \mathrm{~kg} \\
\text { more } 305 \text { day milk (but variations were high). Milk replacer } \\
\text { intake had no effect on first lactation yield } \\
\text { - Season of birth: summer calves had a slightly greater first } \\
\text { lactation yield, probably due to photoperiod on intakes }\end{array}$ \\
\hline Limitations: & $\begin{array}{l}\text { Small number of farms in the sample population, so other herd } \\
\text { management factors could have influenced differences between the } \\
\text { three herds. } \\
\text { There was no association with AFC and } 305 \text { day yield but the } \\
\text { variation between the three farms was small (715, 702 and } 725 \\
\text { days). }\end{array}$ \\
\hline
\end{tabular}

\begin{tabular}{|c|c|}
\hline \multicolumn{2}{|l|}{ Adamczyk et al. (2017) Poland } \\
\hline Population: & Black and White and Red and White dairy HOL-FR cows in Poland \\
\hline Sample size: & $\begin{array}{l}135,496 \text { cows, including } 131,526 \text { of the Black and White breed, and } \\
3970 \text { of the Red and White breed. Data from the National Dairy } \\
\text { Database of Poland }\end{array}$ \\
\hline Intervention details: & $\begin{array}{l}\text { Association of herd size, breed and AFC on lifetime yield ECM and } \\
\text { longevity }\end{array}$ \\
\hline Study design: & Case series \\
\hline Outcome studied: & Culling and AFC \\
\hline $\begin{array}{l}\text { Main findings: } \\
\text { (relevant to PICO question): }\end{array}$ & $\begin{array}{l}\text { - AFC of }<24 \text { months was associated with } 727 \mathrm{~kg} \text { more lifetime } \\
\text { yield (lifetime value of energy corrected milk } 25,184 \mathrm{~kg} \text { ) than } \\
24-31 \text { months (lifetime value of energy corrected milk } \\
24,387 \mathrm{~kg} \text { ) and } 4,401 \mathrm{~kg} \text { more lifetime yield than }>31 \text { months } \\
\text { (lifetime value of energy corrected milk } 20,783 \mathrm{~kg} \text { ) } \\
\text { - There was no significant difference between daily milk yield } \\
\text { (over lifetime: lifetime range was } 5.4 \text { to } 5.9 \text { years, these } \\
\text { being least square mean values) and AFC up to } 31 \text { months } \\
\text { but these were } 1 \mathrm{~kg} / \text { day higher than over } 31 \text { months } \\
\text { - There was no significant difference between AFC and age at } \\
\text { culling in all groups }\end{array}$ \\
\hline Limitations: & $\begin{array}{l}\text { Limited to dairy software recorded herds, which may not be } \\
\text { representative of the general dairy population. } \\
\text { No information on other milk constituents such as milk fat and } \\
\text { protein. other types of research studies have. }\end{array}$ \\
\hline
\end{tabular}




\begin{tabular}{|c|c|}
\hline \multicolumn{2}{|l|}{ Elahi Torshizi (2016) Iran } \\
\hline Population: & Primiparous HOL-FR dairy cows \\
\hline Sample size: & 72,946 cows from 724 herds \\
\hline Intervention details: & Effect of AFC and season on the characteristics of the lactation curve \\
\hline Study design: & Case series \\
\hline Outcome studied: & Shape and area under the curve of first 305 day lactation curve \\
\hline $\begin{array}{l}\text { Main findings: } \\
\text { (relevant to PICO question): }\end{array}$ & $\begin{array}{l}\text { - Seasonal effect was significant on the shape of the lactation } \\
\text { curve. Spring and Winter showed the highest peak values (33 } \\
\mathrm{kg} / \text { day) and Summer/Autumn showed lower peaks (32 } \\
\mathrm{kg} / \text { day). Autumn showed greater persistency in late lactation } \\
\text { (by } 0.5 \mathrm{~kg} / \text { day over the last } 200 \text { to } 305 \mathrm{DIM} \text { ) } \\
\text { - Highest yields ( } 8,000 \mathrm{~kg} \text { ) were associated with AFC between } \\
22-26 \text { months. Beyond this, they reduced considerably (by } \\
600-800 \mathrm{~kg} \text { up to } 32 \text { months) } \\
\text { - For every month increase in AFC between } 18-26 \text { months } \\
\text { there was an increase in } 138 \mathrm{~kg} \text { of } 305 \text { day yield }\end{array}$ \\
\hline Limitations: & $\begin{array}{l}\text { More emphasis was placed on season effects on the lactation } \\
\text { curvethan AFC. } \\
\text { A very good study overall on retrospective data. } \\
\text { Data sources not mentioned in the paper. }\end{array}$ \\
\hline
\end{tabular}

\begin{tabular}{|c|c|}
\hline \multicolumn{2}{|l|}{ Krpalkova et al. (2014) Czech Republic } \\
\hline Population: & $\begin{array}{l}\text { Commercial dairy cows from } 33 \text { farms. } 18 \text { farms were HOL-FR and } \\
\text { eight of Fleckvieh. Seven of mixed HOL/FR and Fleckvieh mixed }\end{array}$ \\
\hline Sample size: & 23,008 cows and 18,139 heifers $(41,147$ animals in total) \\
\hline Intervention details: & AFC, ADWG and milk yield effects on reproduction and profitability \\
\hline Study design: & Case series \\
\hline Outcome studied: & $\begin{array}{l}\text { First service conception risk } \\
\text { Conception rate } \\
\text { Days open } \\
\text { Calving interval } \\
\text { Number of completed lactations } \\
\text { Depreciation costs per cow } \\
\text { MY } \\
\text { Culling rate }\end{array}$ \\
\hline $\begin{array}{l}\text { Main findings: } \\
\text { (relevant to PICO question): }\end{array}$ & $\begin{array}{l}\text { - Herds with more intensive rearing periods (ADWG }>0.8 \\
\mathrm{~kg} / \text { day) had lower conception rates among heifers at first } \\
\text { and overall services } \\
\text { - The differences in conception rates between the group with } \\
\text { the greatest ADWG ( } \geq 0.8 \mathrm{~kg} / \text { day) and the group with the } \\
\text { least ADWG ( } \leq 0.699 \mathrm{~kg} / \text { day) were approximately } 10 \\
\text { percentage points in favour of the least ADWG }\end{array}$ \\
\hline
\end{tabular}




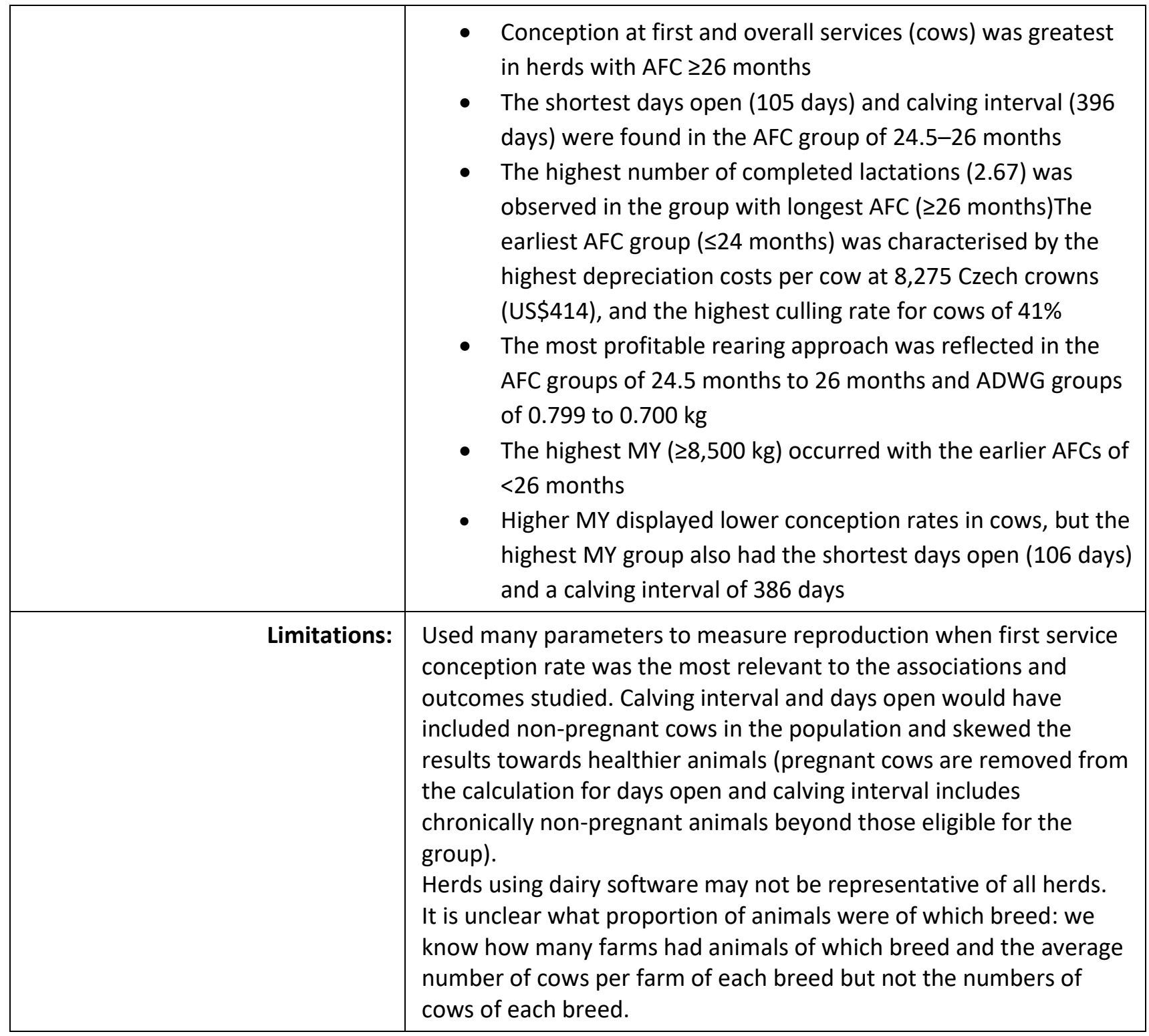

\begin{tabular}{|r|l|}
\hline Wathes et al. (2014) United Kingdom \\
\hline Population: & Primiparous dairy and beef cows \\
\hline Sample size: & Review of 125 articles from 1979-2014 \\
\hline Intervention details: & Influences on AFC and effects of varying AFC \\
\hline Study design: & Review of case series and cohort studies \\
\hline Outcome studied: & $\begin{array}{l}\text { ADWG effects on AFC } \\
\text { Nutritional effects on ADWG } \\
\text { Hormonal effects on puberty } \\
\text { AFC effects on longevity; fertility; MY }\end{array}$ \\
\hline Main findings: & $\begin{array}{l}\text { Average AFC ranges from } 26 \text { months (USA) to } 31 \text { (Kenya) } \\
\text { through } 29 \text { and } 31 \text { (UK and China respectively) }\end{array}$ \\
& $\begin{array}{l}\text { Timing of puberty obviously affects AFC and this is } \\
\text { influenced by both nutrition (ADWG of } 0.82 \mathrm{~kg} / \text { day can bring } \\
\text { on puberty to <10 months) }\end{array}$ \\
\hline
\end{tabular}




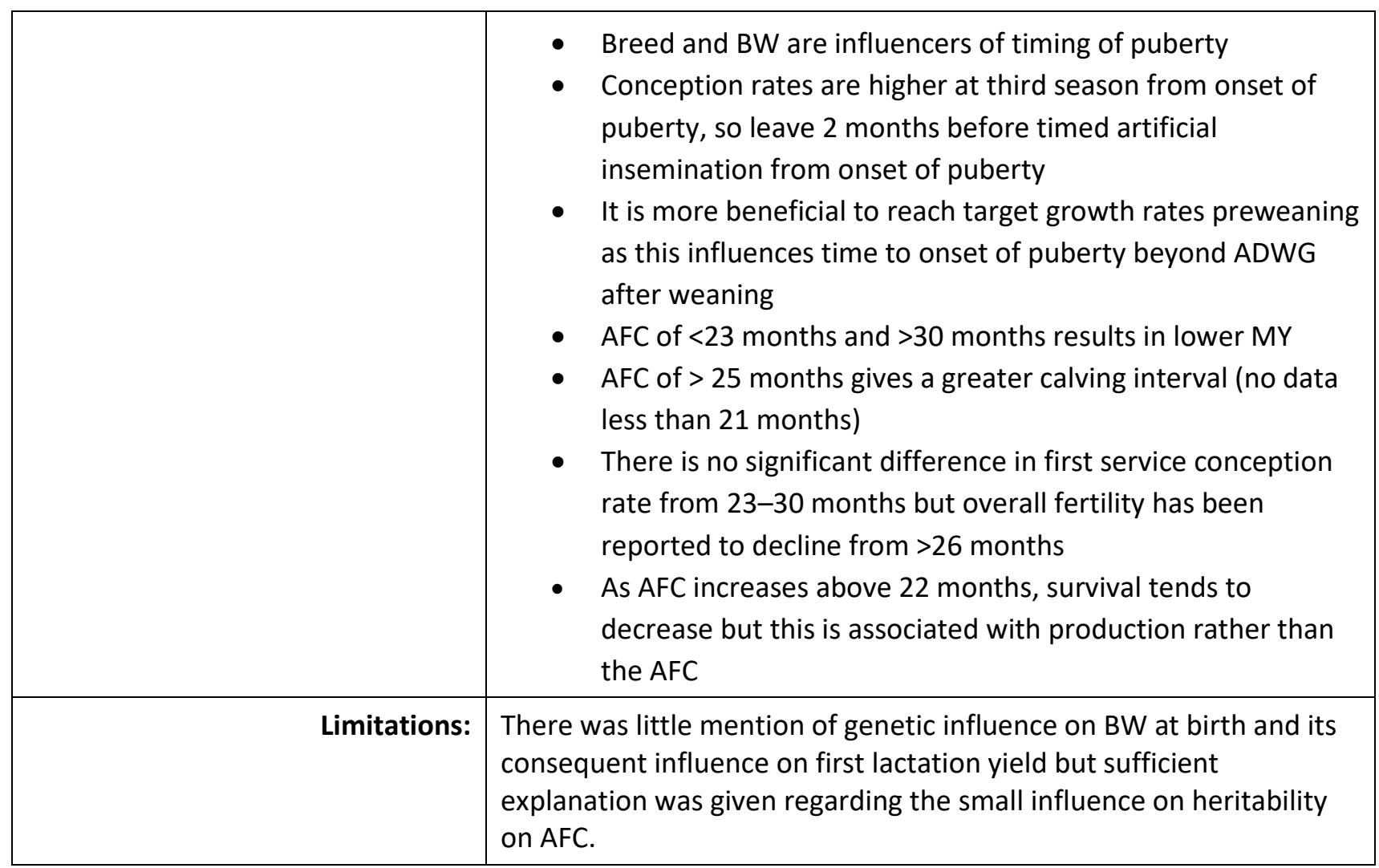

\begin{tabular}{|c|c|}
\hline \\
\hline \multicolumn{2}{|c|}{$\begin{array}{l}\text { Sadeghi-Sefidmazgi et al. (2012) Iran } \\
\text { Population: } \\
\text { Primiparous Holstein dairy cows }\end{array}$} \\
\hline Sample size: & $\begin{array}{l}\text { Number of animals contributing to the dataset are not published. } \\
\text { Data comes from } 10 \text { "large farms", which are described as }>7,000 \\
\text { cows, from three regions in Iran but it is not clear exactly how many. }\end{array}$ \\
\hline Intervention details: & Using dairy software data to determine economic weight (in value) \\
\hline Study design: & Case series \\
\hline Outcome studied: & $\begin{array}{l}\text { Economic Value (US\$) of: } \\
\text { - Milk, fat and protein yield } \\
\text { - } \text { LFC } \\
\text { - SCS } \\
\text { - Mature BW } \\
\text { - Stillbirth } \\
\text { - Calving interval } \\
\text { - } \text { Calving difficulty } \\
\text { Non-return rate }\end{array}$ \\
\hline $\begin{array}{l}\text { Main findings: } \\
\text { (relevant to PICO question): }\end{array}$ & $\begin{array}{l}\text { Economic value of each: } \\
\begin{aligned} \text { - } & \text { Milk/kg } \$ 0.15 \\
\text { - } & \text { Fat } \% \$ 1.36 \\
\text { - } & \text { Protein } \%-\$ 1.02\end{aligned}\end{array}$ \\
\hline
\end{tabular}




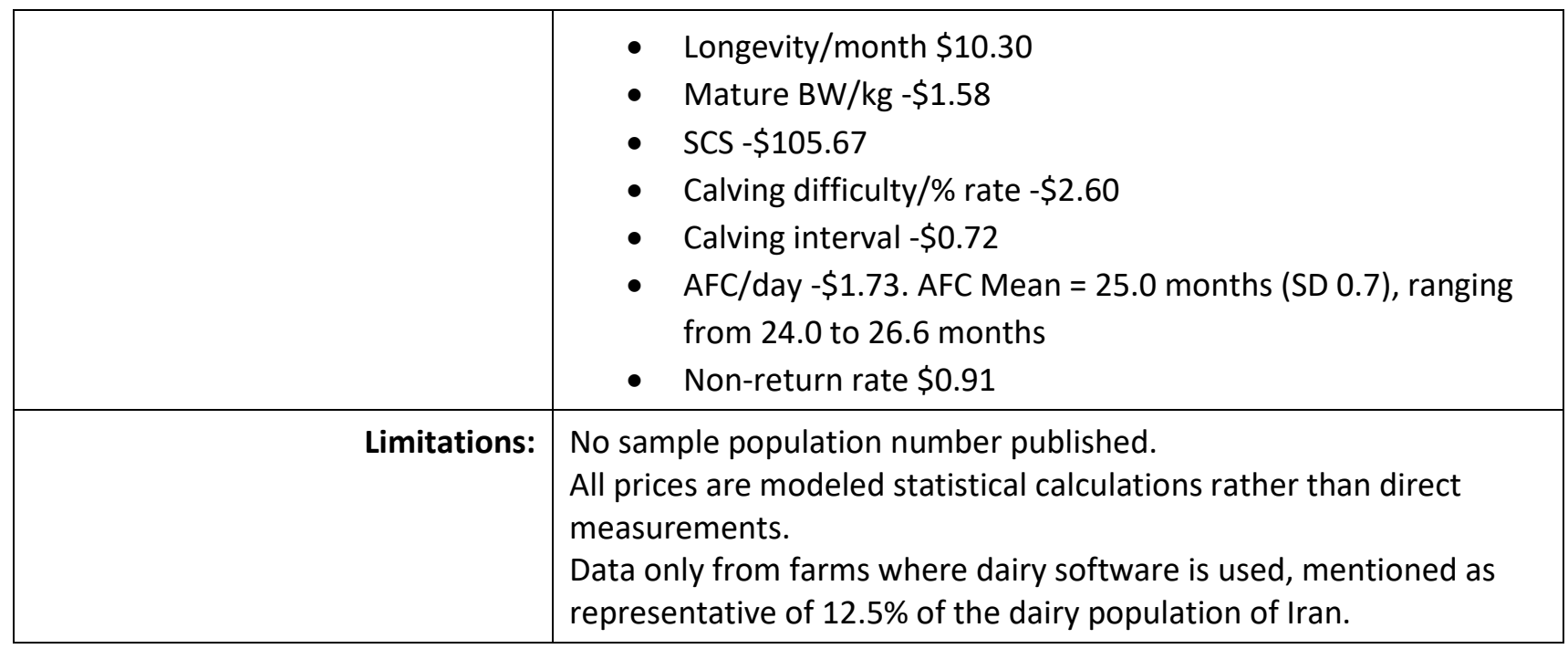

Davis Rincker et al. (2011) United States of America

\begin{tabular}{|c|c|}
\hline Population: & Primiparous Holstein dairy cows \\
\hline Sample size: & 80 heifers $n=40$ in two intervention groups \\
\hline Intervention details: & $\begin{array}{l}\text { Intensive and non-intensive diets in preweaning } \\
\text { Details in paper on breakdown of diet but overview below: } \\
\text { Intensive: } 1.12 \mathrm{~kg} \mathrm{DM} / \text { day milk replacer consisting of } 30.6 \% \mathrm{CP} \text { and } \\
16.1 \% \mathrm{fat} / \mathrm{kg} \mathrm{DM} \text {. } \\
\text { Non-intensive: } 0.58 \mathrm{~kg} \mathrm{DM} / \text { day milk replacer consisting of } 21.5 \% \mathrm{CP} \\
\text { and } 21.5 \% \mathrm{fat} / \mathrm{kg} \mathrm{DM} \text {. }\end{array}$ \\
\hline Study design: & Randomised control trial \\
\hline Outcome studied: & $\begin{array}{l}\text { Conception age } \\
\text { AFC } \\
\text { ADWG } \\
\text { BCS at mating } \\
\text { Economic return }\end{array}$ \\
\hline $\begin{array}{l}\text { Main findings: } \\
\text { (relevant to PICO question): }\end{array}$ & $\begin{array}{l}\text { - ADWG was } 0.2 \mathrm{~kg} / \text { day greater preweaning on the intensive } \\
\text { diet ( } 0.64 \mathrm{vs} 0.44 \mathrm{~kg} / \text { day) } \\
\text { - ADWG post-weaning was not significantly different } \\
\text { - } \text { intensive diet group } \\
\text { - Milk yield (to } 150 \text { DIM and predicted } 305 \text { day yield) was not } \\
\text { significantly different from each group } \\
\text { - BCS at mating was not significantly different } \\
\text { - Economic return was marginally in favour of intensive } \\
\text { feeding but return could be positive or negative based on } \\
\text { milk prices }\end{array}$ \\
\hline Limitations: & $\begin{array}{l}\text { Out of the } n=40 \text { heifers in each group, } 38 \text { (out of } 80 \text { total) were } \\
\text { excluded (not known exactly how many from each group were } \\
\text { excluded) for reasons of disease, late attainment of pregnancy, } \\
\text { failure to conceive after three services, abortion, low MY and } \\
\text { lameness. }\end{array}$ \\
\hline
\end{tabular}




\begin{tabular}{|l|l|}
\hline & $\begin{array}{l}\text { AFC was found to have no effect on yield but there were only 15 } \\
\text { days between each group so differences were not significant. }\end{array}$ \\
\hline
\end{tabular}

\begin{tabular}{|r|l|}
\hline \multicolumn{2}{|l|}{ Haworth et al. (2008) Australia } \\
\hline Population: & Primiparous dairy cows \\
\hline Sample size: & 442 cows from one farm \\
\hline Intervention details: & Effects of varying AFC \\
\hline Study design: & Case series \\
\hline Outcome studied: & $\begin{array}{l}\text { First lactation MY } \\
\text { Lifetime MY } \\
\text { Longevity }\end{array}$ \\
\hline Main findings: & $\begin{array}{c}\text { AFC varied from 700-1200 days (22-29 months) with most } \\
\text { calving at 22-32 months } \\
\text { There was no significant difference in the influence of AFC } \\
\text { on first lactation MY, subsequent lactation yields and } \\
\text { lifetime yield or on longevity }\end{array}$ \\
\hline Limitations: & $\begin{array}{l}\text { Cows giving <30 litres/day had greater longevity and cows } \\
\text { giving >30 litres/day had higher yields and lower longevity }\end{array}$ \\
\hline $\begin{array}{l}\text { Very small sample number to make conclusions over effects of AFC } \\
\text { on lifetime parameters: this is why yield in the first lactation had } \\
\text { more effect on outcomes than AFC. } \\
\text { One farm had huge variation in AFC: this implies that there may } \\
\text { have been many other factors in heifer management that could have } \\
\text { influenced the yield result later in life. }\end{array}$ \\
\hline
\end{tabular}

\begin{tabular}{|c|c|}
\hline \multicolumn{2}{|c|}{ Ruiz-Sanchez et al. (2007) United States of America } \\
\hline Population: & DHI contributing herds to National US Dairy Program \\
\hline Sample size: & 248,230 cow records from 3,042 herds in DHI program \\
\hline Intervention details: & Retrospective analysis of data from US Dairy Program database. \\
\hline Study design: & $\begin{array}{l}\text { Case series: Linking association of yield, AFC and genetic heritability } \\
\text { traits on herd data in "low" and "high" environment herds. } \\
\text { High and Low environment herds were classified by upper and lower } \\
\text { quartile respectively of herd-year season combination of mean and } \\
\text { SD for MY. }\end{array}$ \\
\hline Outcome studied: & $\begin{array}{l}\text { First lactation MY } \\
\text { AFC } \\
\text { Genetic associations of AFC and yield using breeding values and sire } \\
\text { heritability traits } \\
\text { Lifetime MY } \\
\text { Longevity }\end{array}$ \\
\hline $\begin{array}{l}\text { Main findings: } \\
\text { (relevant to PICO question): }\end{array}$ & $\begin{array}{l}\text { - AFC had a mean of } 28.4 \text { months (SD 3.4) in lower quartile } \\
\text { herds and } 25.8 \text { months (SD 2.9) in higher quartile herds }\end{array}$ \\
\hline
\end{tabular}




\begin{tabular}{|l|l|}
\hline - & $\begin{array}{l}\text { First lactation MY in lower quartile herds was 8,450 kg (SD } \\
1,448 \text { ) and 10,821 kg (SD 1,946) in higher quartile herds } \\
\text { Genetic associations of AFC and MY were negative } \\
\text { regardless of herd "level", suggesting a genetic by } \\
\text { environment interaction but the author states that this } \\
\text { should be interpreted with caution as genetic relationships } \\
\text { are dynamic within herds, especially in situations of } \\
\text { population selection. } \\
\text { Limitations: }\end{array}$ \\
\hline & $\begin{array}{l}\text { Lower quartile environment herds had genetic correlation of } \\
\text {-0.31 and higher herds had one of -0.51 for both AFC and MY }\end{array}$ \\
& $\begin{array}{l}\text { Limited to herds contributing to the DHI US dataset and therefore } \\
\text { Historical dataset (1987-1994) and over multiple years, where many } \\
\text { other factors may have influenced the dataset (especially in } \\
\text { improvement programs). } \\
\text { Linking genetic heritability to environmental factors and using AFC } \\
\text { as an outcome measurement is very risky: AFC is influenced by every } \\
\text { management factor in youngstock rearing, so linking genetics to this } \\
\text { is extremely challenging. This is recognised by the authors as a } \\
\text { limitation also. }\end{array}$ \\
\hline
\end{tabular}

\begin{tabular}{|c|c|}
\hline \multicolumn{2}{|l|}{ Banos et al. (2007) United Kingdom } \\
\hline Population: & Dairy cows \\
\hline Sample size: & $\begin{array}{l}228,229 \text { records from data from the UK national fertility database } \\
1997-2005\end{array}$ \\
\hline Intervention details: & AFC, age at second calving and BCS of dam in gestation \\
\hline Study design: & Case series \\
\hline Outcome studied: & $\begin{array}{l}\text { Calving interval } \\
\text { Days between calving and first service } \\
\text { Number of inseminations per conception } \\
\text { Non-return to oestrus } 56 \text { days after first insemination } \\
\text { MY at third test day ( } 3 \text { months into lactation) }\end{array}$ \\
\hline $\begin{array}{l}\text { Main findings: } \\
\text { (relevant to PICO question): }\end{array}$ & $\begin{array}{l}\text { - AFC of } 18 \text { to } 23 \text { months of age, produced } 4.5 \% \text { more ï-[rst } \\
\text { lactation daily milk, had } 7 \% \text { higher BCS, and had their ï-? } \mathrm{rrst} \\
\text { service } 3 \text { days earlier than cows whose dams calved late ( } 30 \\
\text { to } 36 \text { months) } \\
\text { - AFC of } 18-23 \text { months had } 7 \% \text { more inseminations and had a } \\
7.5 \% \text { higher rate of return to oestrus }\end{array}$ \\
\hline Limitations: & $\begin{array}{l}\text { It is assumed that many of the cows included would have been } \\
\text { Holstein breed but it is not specifically stated in the paper. } \\
\text { Historical dataset (1987-1994) and over multiple years, where many } \\
\text { other factors may have influenced the dataset (especially in } \\
\text { improvement programs such as the fertility database). } \\
\text { BCS is subjective and variable in recording. } \\
\text { Calving interval is historical and not considered a useful parameter } \\
\text { in } 2019 \text { dairies. }\end{array}$ \\
\hline
\end{tabular}




\begin{tabular}{|c|c|}
\hline \multicolumn{2}{|c|}{ Ettema \& Santos (2004) United States of America } \\
\hline Population: & Primiparous Holstein dairy cows \\
\hline \multirow[t]{4}{*}{ Sample size: } & 1,905 heifers in three groups of AFC: \\
\hline & 1. AFC of $<700$ days, $n=514$ (Low) \\
\hline & 2. AFC of $701-750$ days, $n=917$ (Medium) \\
\hline & 3. AFC of $>750$ days, $n=474$ (High) \\
\hline Intervention details: & Varying AFC and its effects on productivity \\
\hline Study design: & Case series \\
\hline Outcome studied: & $\begin{array}{l}\text { MY } \\
\text { Conception rates } \\
\text { Disease rates after birth } \\
\text { Economic income }\end{array}$ \\
\hline $\begin{array}{l}\text { Main findings: } \\
\text { (relevant to PICO question): }\end{array}$ & $\begin{array}{l}\text { Mean group conception rates at first artificial insemination } \\
\text { in low, middle and high groups were } 76.9 \%, 64.4 \% \text { and } \\
44.9 \% \text { respectfully } \\
\text { MY in first lactation per group: low }(33.4 \pm 0.23 \mathrm{~kg} / \mathrm{d}) \text {; } \\
\text { medium }(34.4 \pm 0.18 \mathrm{~kg} / \mathrm{d}) \text {; high }(34.7 \pm 0.24 \mathrm{~kg} / \mathrm{d}) \text { and the } \\
\text { low group tended to give } 310 \mathrm{~kg} \text { less milk in first lactation } \\
\text { - Heifers in the middle AFC group had economic income of } \\
\text { between US } \$ 138.33 \text { and US\$98.81 compared with those in } \\
\text { the low and high groups AFC had no influence on post- } \\
\text { partum diseases }\end{array}$ \\
\hline Limitations: & $\begin{array}{l}\text { It is mentioned by the authors that AFC can be confounded with BW, } \\
\text { as this is recognised to influence first lactation yields. }\end{array}$ \\
\hline
\end{tabular}

\begin{tabular}{|c|c|}
\hline \multicolumn{2}{|l|}{ Nilforooshan \& Edriss (2004) Iran } \\
\hline Population: & Primiparous Holstein dairy cows \\
\hline Sample size: & 12,082 cow records from 42 herds. Data from 1991-2001 \\
\hline Intervention details: & Varying AFC effects on production and longevity \\
\hline Study design: & Case series \\
\hline Outcome studied: & $\begin{array}{l}\text { First lactation yield } \\
\text { First lactation fat yield } \\
\text { Longevity }\end{array}$ \\
\hline $\begin{array}{l}\text { Main findings: } \\
\text { (relevant to PICO question): }\end{array}$ & $\begin{array}{l}\text { - AFC was optimal between } 22-24 \text { months for first lactation } \\
\text { yield, peaking at 7,000 kg (ranging } 5,700 \mathrm{~kg} \text { at } 21 \text { months to } \\
6,100 \mathrm{~kg} \text { at } 34 \text { months). This is true also for fat yield ( } 190 \mathrm{~kg} \\
\text { for } 22-24 \text { months versus } 170 \mathrm{~kg} \text { for }<22 \text { months and } 175 \mathrm{~kg} \\
\text { at } 34 \text { months) } \\
\text { - AFC }<22 \text { months was detrimental for first lactation yield by } \\
\text { up to } 800 \mathrm{~kg}\end{array}$ \\
\hline
\end{tabular}




\begin{tabular}{|c|l|}
\hline \multirow{2}{*}{ Limitations: } & $\begin{array}{l}\text { AFC was not seen to directly influence longevity but } \\
\text { productivity over lifetime positively influenced longevity. } \\
\text { Heritability of AFC was very low (0.082) }\end{array}$ \\
\hline $\begin{array}{l}\text { Data collected over a long period of time and many other factors } \\
\text { could influence outcomes, especially if the herds are in } \\
\text { improvement programs. } \\
\text { Data from software recorded herds may be from better managed } \\
\text { herds and therefore not be representative of the country } \\
\text { population. }\end{array}$ \\
\hline
\end{tabular}

\begin{tabular}{|c|c|}
\hline \multicolumn{2}{|l|}{ Pirlo et al. (2011) Italy } \\
\hline Population: & Primiparous Holstein dairy cows \\
\hline Sample size: & 1,048,942 cow records from Italy between 1992 and 1997 \\
\hline Intervention details: & $\begin{array}{l}\text { Retrospective on-farm data analysis of AFC effects on first lactation } \\
\text { yield and economic return }\end{array}$ \\
\hline Study design: & Case series \\
\hline Outcome studied: & First lactation yield and economic return \\
\hline $\begin{array}{l}\text { Main findings: } \\
\text { (relevant to PICO question): }\end{array}$ & $\begin{array}{l}\text { - Optimum AFC was between } 22-24 \text { months. } \\
\text { - Cows calving with an AFC of } 36 \text { to } 29 \text { months gave an } \\
\text { average of } 170.2 \mathrm{~kg} \text { less milk over the first lactation. } \\
\text { - Cows calving with an AFC of } 29-24 \text { months gave a mean } \\
\text { average of } 254.9 \mathrm{~kg} \text { less milk in the first lactation. } \\
\text { - Cows calving with an AFC of }<20 \text { months gave a mean } \\
\text { average of } 589.8 \mathrm{~kg} \text { less milk in the first lactation. } \\
\text { - Reducing AFC between } 26-22 \text { months increased the } \\
\text { economic return by US\$41.5 and US\$24/heifer. Delaying AFC } \\
\text { beyond } 26 \text { months reduced returns due to an increase in } \\
\text { rearing costs. }\end{array}$ \\
\hline Limitations: & $\begin{array}{l}\text { Historical data and collected over several years, so other factors } \\
\text { could have influenced results, such as improvement programs and } \\
\text { environmental factors. }\end{array}$ \\
\hline
\end{tabular}

\begin{tabular}{|r|l|}
\hline \multicolumn{1}{|c|}{ Berry \& Cromie (2009) Republic of Ireland } \\
\hline Population: & Primiparous Holstein-Friesian seasonal grazing dairy cows \\
\hline Sample size: & $\begin{array}{l}196,120 \text { cow records from herds of over } 30 \text { cows in the Irish Cattle } \\
\text { Breeding Federation from 2000-2006 }\end{array}$ \\
\hline Intervention details: & Varying effects of AFC \\
\hline Study design: & Case series \\
\hline Outcome studied: & $\begin{array}{l}\text { First lactation MY } \\
\text { Fertility } \\
\end{array}$ \\
\hline
\end{tabular}




\begin{tabular}{|c|c|}
\hline $\begin{array}{l}\text { Main findings: } \\
\text { (relevant to PICO question): }\end{array}$ & $\begin{array}{l}\text { - AFC ranged from 660-1156 days with peaks at } 24 \text { and } 36 \\
\text { months } \\
\text { - AFC decreased linearly, associated with first lactation yield of } \\
\text { milk, fat and protein by } 55.5 \mathrm{~kg}, 0.6 \mathrm{~kg} \text { and } 2.3 \mathrm{~kg} \\
\text { respectively for each month from } 20 \text { months } \\
\text { - AFC was associated with survival to second, third, fourth and } \\
\text { fifth parity } \\
\text { - Animals with an AFC of } 24 \text { months had greatest odds of } \\
\text { survival in the first lactation (odds ratio of around 1.0), } \\
\text { decreasing to an odds ratio of around } 0.7 \text { for AFCs from } 28- \\
38 \text { months } \\
\text { - There was no association found with AFC and survival above } \\
\text { the first parity }\end{array}$ \\
\hline Limitations: & $\begin{array}{l}\text { Collection of data over } 6 \text { years and other factors could influence the } \\
\text { outcomes studied such as herd improvement programs and } \\
\text { environment. } \\
\text { Herds specified as seasonal grazing herds but not specified whether } \\
\text { spring or autumn calving. This may affect yield from grazing herds in } \\
\text { Ireland as well as heat effects in Spring calving herds (even in Ireland } \\
\text { it can reach over } 24^{\circ} \mathrm{C} \text { ). } \\
\text { Very large range of AFC. Numbers of animals in distribution graphs } \\
\text { peaked at } 24 \text { and } 36 \text { months (very far apart): this indicates a great } \\
\text { variety of management factors that are influencing heifer growth, } \\
\text { which may also affect the outcomes measured. }\end{array}$ \\
\hline
\end{tabular}

\begin{tabular}{|c|c|}
\hline \multicolumn{2}{|l|}{ Changee et al. (2013) Korea } \\
\hline Population: & Holstein dairy cows \\
\hline Sample size: & 276,573 cow records: Data from 1998-2004 \\
\hline Intervention details: & Varying AFC on production effects \\
\hline Study design: & Case series \\
\hline Outcome studied: & $\begin{array}{l}\text { First two calving intervals } \\
\text { Days in milk for lifetime } \\
\text { Lifespan } \\
\text { Milk income } \\
\text { Lifetime profit }\end{array}$ \\
\hline $\begin{array}{l}\text { Main findings: } \\
\text { (relevant to PICO question): }\end{array}$ & $\begin{array}{l}\text { - Profit increased by US\$3.45 per day of lifetime increase } \\
\text { - AFC had very few heritability traits (<0.14 on all outcomes } \\
\text { studied) } \\
\text { - Lifetime profit increased by US\$727.30 by reducing AFC from } \\
\text { 32-22 months } \\
\text { - Optimum AFC for lifetime profit was between } 22.5-23.5 \\
\text { months }\end{array}$ \\
\hline Limitations: & $\begin{array}{l}\text { Collection of data over } 6 \text { years and other factors could influence the } \\
\text { outcomes studied such as herd improvement programs and } \\
\text { environment. }\end{array}$ \\
\hline
\end{tabular}


Lifetime profit had a very large residual spread over 3000 days $(6$ lactations) which could skew some of the conclusions on profitability for later lactations.

\section{Appraisal, application and reflection}

This Knowledge Summary includes 17 papers from 10 countries: four from USA; three from Iran; three from UK and one each from Korea, Ireland, Italy, Poland, Czech Republic, Norway and Australia. Together, they include over 2,645,158 cow records in 15 case series, one randomised control trial and one review. They cover scientific literature published from 1979-2018 (pre-2000 references coming from Wathes et al. (2014). Case series mostly include data taken from large farms with computerised dairy records. Many of these include farms on DHI programs (Elahi Torshizi, 2016 and Ettema \& Santos, 2004) and cover data spreading over 2-5 years (Berry \& Cromie, 2009; Eastham et al., 2018 and Nilforooshan \& Edriss, 2004). Although this technique gives large sample population numbers, it may also create confounding factors: farms that use computer records and that participate in herd improvement schemes may not be representative of all dairy farms and are already skewing data towards the more advanced farm management systems. Therefore the AFCs recorded as the range within the country may be lower than the real picture. Also, if data from farms on improvement programs cover several years, it may be likely that the AFC and yields (and diets, disease management, heat abatement, etc.) may improve anyway, also confounding results.

\section{Outcomes of AFC}

Generally, MY data is well recorded on farms, as it represents the main form of income to the businesses. Only one of the reviewed papers mention the confounding effect of BW at calving on first lactation 305 day yield (Ettema \& Santos, 2004). As AFC also influences first lactation 305 day yield, further research including this parameter would be preferable in future to attempt to separate these effects.

In contrast, fertility data is not so clear. Some papers use calving interval (the mean average between calvings in days); some use days open (the average number of days from calving to confirmed pregnancy) and others use first service conception rate (percentage of cows pregnant to the first service after voluntary waiting period). Unfortunately, calving interval is a very historical parameter: it generally represents cows that got pregnant at least 9 months to 1 year previous to the date it is recorded. Therefore, when measuring AFC effects in calving interval, the records may not be representative of the AFC group from the year studied, or include the confounding effect of culling in calculating calving intervals. Similarly, days open requires at least 85-120 days from calving to calculate a figure, so to be representative of the sample population, it must be recorded over at least a year. Again, this means that the AFC recorded may not be the same group of those providing the days open result. Also, when assessing improvements in days open, one must consider that it will go up before it goes down: only non-pregnant cows are included in the calculation: when a cow gets pregnant, she is removed from the "pool" of animals contributing to the data. Therefore, if more cows get pregnant, the pool of non-pregnant animals is skewed to a larger figure as it is more influenced by chronically non-pregnant cows. When these leave the population, the days open figure will finally go down but this may be a long time from the AFC figure recorded from the farm.

So the more representative figure for testing AFC is the first service conception rate used in Ettema \& Santos (2004) compared to calving interval and days open used in Krpalkova (2014) and Eastham et al. (2018).

Two papers showed an influence on longevity from AFC, with those calving in the 24 month window having a high odds ratio of surviving their first lactation of 0.8-1.0 and those calving later, beyond 28 months having an odds ratio of $<0.72$ (Eastham et al. 2018 and Berry \& Cromie, 2009). Others found no significant, direct effect. Survival in dairy cows is strongly influenced by productivity: whether this is from low yields, low fertility or presence of disease. AFC is linked to lower yields in ranges outside of 22-26 months, which could influence a culling decision but this decision may be more likely to be made from one of the other factors first. 
As far as profitability is concerned, in order to calculate the effect of AFC on yield and fertility, a considerable amount of modelling is required. There is a lot of potential here for different researchers to include different parameters into their model: feed prices change by country and over time, as does economy in general, therefore the conclusion of one paper may not be comparable with another. As the effects of AFC (yield, fertility and culling) are influenced by so many other factors, the model is required to have many inputs, from labour, feed price, veterinary costs, rent, energy costs, disease rates, etc. When this is calculated, it is easy for some groups to miss some inputs and also, without considerable detail, avoid double-counting. For this reason, it is not advisable to take a value published from these papers and directly translate that to the reader's situation.

\section{Application and reflection}

The clinical bottom line has far-reaching consequences for advisors on dairy farms. AFC is a key performance indicator of heifer management, including diet quality and availability, disease risk, insemination techniques and preweaning growth. A knowledge of the evidence that sets a target window of 22-26 months is a crucial tool in youngstock management advice. Not reaching these goals can be detrimental to both fertility and milk income, so hitting these targets gives both foundation and drive to improvement projects throughout the industry.

Further research in the interaction of body weight at birth and AFC on first lactation yield would provide more clarity on the individual effects of both on production.

\section{Methodology Section}

Three databases were used to search this PICO. The author has chosen to exclude papers before 2000, as dairy records before this date were limited and the management/genetics of dairy cows since this date have changed considerably in many countries through improvement schemes. One review Wathes et al. (2014) mentions papers back to 1979 and is a comprehensive work summarising much of the intervening period, so as it is included in this review, it was felt by the author to be a sufficient summary of the evidence pre- 2000 .

The PICO focused on effects rather than inputs to AFC so articles were excluded that concentrated on influences on AFC rather than consequences of varying AFC.

There have been publications linking AFC to genetic heritability traits, as this is an attractive theme to offer from genetic improvement (semen) companies. However, it has been evident from the literature that heritability of AFC is very low and not a significant factor (Ruiz-Sanchez et al. 2007): many other publications also make this conclusion. For this reason, the author has excluded genetic heritability papers from the Knowledge Summary.

\begin{tabular}{|c|c|}
\hline $\begin{array}{r}\text { Databases searched and dates } \\
\text { covered: }\end{array}$ & $\begin{array}{l}\text { PubMed (NCBI) February } 28^{\text {th }} 2019 \text {; CAB Abstracts March } 1^{\text {st }} 2019 \text {; } \\
\text { Google Scholar March } 1^{\text {st }} 2019 \text { ). Filtered from } 2000 \text { to } 2019\end{array}$ \\
\hline Search terms: & $\begin{array}{l}\text { Using Advanced Search keywords on words based only in the PICO } \\
\text { topic } \\
\text { PubMed: } \\
\text { ((((((bovi* OR cattle OR cow\$ OR heifer))) AND (([age at first calving. } \\
\text { OR AFC OR [calving age])))) AND milk) AND ((yield OR volume OR } \\
\text { weight)) AND ("2000/01/01"[PDat] : "2019/12/31"[PDat]) }\end{array}$ \\
\hline
\end{tabular}




\begin{tabular}{|l|l|}
\hline CAB Abstracts: \\
(cattle OR cow\$ OR heifer OR bovi*) AND ([age at first calving] OR \\
AFC) AND ( yield OR production OR lactation) AND (reproduc* OR \\
fertility) Limiters: Scholarly (Peer Reviewed) Journals; Date of \\
Publication: 20000101-20191231
\end{tabular}

\begin{tabular}{|c|c|}
\hline \multicolumn{2}{|l|}{ Exclusion / Inclusion Criteria } \\
\hline Exclusion: & $\begin{array}{l}\text { - Pre-2000. Heifer management and breeds of Holstein Dairy } \\
\text { cattle have changed significantly since } 2000 \text { as dairies across } \\
\text { the world increasingly use computer software and targeted } \\
\text { strategies. } \\
\text { - Bos taurus only } \\
\text { - Papers concentrating on growth rates in youngstock and AFC } \\
\text { - Papers concentrating on nutritional protocols in youngstock } \\
\text { and AFC }\end{array}$ \\
\hline Inclusion: & $\begin{array}{l}\text { - Associations between AFC and yield or reproduction in Bos } \\
\text { - } \text { taurus dairy cattle } \\
\text { - Assessments of factors affecting AFC and performance } \\
\text { - } \text { mentioned in the population studied sections } \\
\text { - Peer-reviewed papers only }\end{array}$ \\
\hline
\end{tabular}

\begin{tabular}{|c|c|c|c|c|c|}
\hline \multicolumn{6}{|c|}{ Search Outcome } \\
\hline Database & $\begin{array}{c}\text { Number of } \\
\text { results }\end{array}$ & $\begin{array}{l}\text { Excluded - } \\
\text { pre } 2000\end{array}$ & $\begin{array}{c}\text { Excluded - } \\
\text { non-relevance } \\
\text { to PICO }\end{array}$ & $\begin{array}{l}\text { Excluded - } \\
\text { related to factors } \\
\text { before calving } \\
\text { rather than AFC }\end{array}$ & $\begin{array}{c}\text { Total relevant } \\
\text { papers }\end{array}$ \\
\hline PubMed & 472 & 91 & 362 & 4 & 15 \\
\hline $\begin{array}{l}\mathrm{CAB} \\
\text { abstracts }\end{array}$ & 677 & 296 & 359 & 14 & 8 \\
\hline $\begin{array}{l}\text { Google } \\
\text { Scholar }\end{array}$ & 201 & 76 & 118 & 3 & 4 \\
\hline \multicolumn{5}{|c|}{ Total relevant papers when duplicates removed } & 17 \\
\hline
\end{tabular}


The author declares no conflicts of interest.

\section{REFERENCES}

1. Adamczyk, K., Makulska, J., Jagusiak, W. \& Węglarz, A. 2017. Associations between strain, herd size, age at first calving, culling reason and lifetime performance characteristics in Holstein-Friesian cows. Animal 11 (2): 327-334. DOI: http://dx.doi.org/10.1017/S1751731116001348

2. Banos, G., Brotherstone, S. \& Coffey, M.P. 2007. Prenatal maternal effects on body condition score, female fertility, and milk yield of dairy cows. Journal of Dairy Science 90 (7): 3490-3499. DOI: http://dx.doi.org/10.3168/ids.2006-809

3. Berry, D.P. \& Cromie, A.R. 2009. Associations between age at first calving and subsequent performance in Irish spring calving Holstein-Friesian dairy cows. Livestock Science 123 (1): 44-54. DOI: http://dx.doi.org/10.1016/j.livsci.2008.10.005

4. Bond, G.B., von Keyserlingk, M.A., Chapinal, N., Pajor, E.A. \& Weary, D.M. 2015. Among farm variation in heifer BW gains. Animal 9 (11): 1884-1887. DOI: http://dx.doi.org/10.1017/S175173111500097X

5. Changhee, D., Nidarshani, W., Kwanghyun, C., Yunho, C., Taejeong, C., Byungho, P. \& Donghee, L. 2013. The Effect of Age at First Calving and Calving Interval on Productive Life and Lifetime Profit in Korean Holstein. Asian Autralasian Journal of Animal Science 26 (11): 1511-1517. DOI: https://doi.org/10.5713/ajas.2013.13105

6. Chester-Jones, H., Heins, B.J., Ziegler, D., Schimek, D., Schuling, S., Ziegler, B., de Ondarza, B., Sniffen, C.J. \& Broadwater, N. 2017. Relationships between early-life growth, intake, and birth season with first-lactation performance of Holstein dairy cows. Journal of Dairy Science 100 (5): 3697-3704. DOI: http://dx.doi.org/10.3168/jds.2016-12229

7. Davis Rincker, L.E., Vandehaar, M.J., Wolf, C.A., Liesman, J.S., Chapin, L.T. \& Weber Nielsen, M.S. 2011. Effect of intensified feeding of heifer calves on growth, pubertal age, calving age, milk yield, and economics. Journal of Dairy Science 94 (7): 3554-3567. DOI: http://dx.doi.org/10.3168/jds.2010-3923

8. Eastham, N.T., Coates, A., Cripps, P., Richardson, H., Smith, R. \& Oikonomou, G. 2018. Associations between age at first calving and subsequent lactation performance in UK Holstein and HolsteinFriesian dairy cows. PlosOne 13 (6): e0197764. DOI: http://dx.doi.org/10.1371/journal.pone.0197764

9. Elahi Torshizi, M. 2016. Effects of season and age at first calving on genetic and phenotypic characteristics of lactation curve parameters in Holstein cows. Journal of Animal Science and Technology 58 (8): doi: 10.1186/s40781-016-0089-1. DOI: http://dx.doi.org/10.1186/s40781-0160089-1

10. Ettema, J.F. \& Santos, J.E. 2004. Impact of age at calving on lactation, reproduction, health, and income in first-parity Holsteins on commercial farms. Journal of Dairy Science 87 (8): 2730-2742. DOI: http://dx.doi.org/10.3168/ids.S0022-0302(04)73400-1

11. Haworth, G.M., Tranter, W.P., Chuck, J.N., Cheng, Z. \& Wathes, D.C. 2008. Relationships between age at first calving and first lactation milk yield, and lifetime productivity and longevity in dairy cows. Veterinary Record 162 (20): 643-647. DOI: http://dx.doi.org/10.1136/vr.162.20.643

12. Krpalkova, L., Cabrera, V.E., Kvapilik, J., Burdych, J. \& Crump, P. 2014. Associations between age at first calving, rearing average daily weight gain, herd milk yield and dairy herd production, reproduction, and profitability. Journal of Dairy Science 97 (10): 6573-6582.

DOI: http://dx.doi.org/10.3168/jds.2013-7497 
13. MacDonald, K.A., Penno, J.W., Bryant, A.M. \& Roche, J.R. 2005. Effect of feeding level pre- and postpuberty and body weight at first calving on growth, milk production, and fertility in grazing dairy cows. Journal of Dairy Science 88 (9): 3363-3375. DOI: http://dx.doi.org/10.3168/jds.S00220302(05)73020-4

14. Nilforooshan, M.A. \& Edriss, M.A. 2004. Effect of age at first calving on some productive and longevity traits in Iranian Holsteins of the Isfahan province. Journal of Dairy Science 87 (7): 2130-2135. DOI: http://dx.doi.org/10.3168/ids.S0022-0302(04)70032-6

15. Pirlo, G., Miglior, F. \& Speroni, M. 2011. Effect of age at first calving on production traits and on difference between milk yield returns and rearing costs in Italian Holsteins. Journal of Dairy Science 83 (3): 603-608. DOI: http://dx.doi.org/10.3168/jds.S0022-0302(00)74919-8

16. Ruiz-Sanchez, R., Blake, R.W., Castro-Gamez, H.M.A., Sanchez, F., Montaldo, H.H. \& Castillo-Juarez, H. 2007. Changes in the Association Between Milk Yield and Age at First Calving in Holstein Cows with Herd Environment Level for Milk Yield. Journal of Dairy Science 90: 4830-4837.

DOI: http://dx.doi.org/10.3168/jds.2007-0156

17. Sadeghi-Sefidmazgi, A., Moradi-Shahrbabak, M., Nejati-Javaremi, A., Miraei-Ashtiani, S.R. \& Amer, P.R. 2012. Breeding objectives for Holstein dairy cattle in Iran. Journal of Dairy Science 95: 3406-3418. DOI: http://dx.doi.org/10.3168/jds.2011-4573

18. Storli, K.S., Klemetsdal, G., Volden, H. \& Salte, R. 2017. The relationship between Norwegian Red heifer growth and their first-lactation test-day milk yield: A field study. Journal of Dairy Science 100 (9): 7602-7612. DOI: http://dx.doi.org/10.3168/ids.2016-12018

19. Wathes, D.C., Pollot, G.E., Johnson, K.F., Richardson, H. \& Cooke, J.S. 2014. Heifer fertility and carry over consequences for life time production in dairy and beef cattle. Animal 8 (1): 91-104.

DOI: http://dx.doi.org/10.1017/S1751731114000755 


\section{EVIIDEFeE

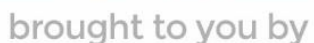 \\ RCVS KNOWLEDGE}

\section{Intellectual Property Rights}

Authors of Knowledge Summaries submitted to RCVS Knowledge for publication will retain copyright in their work, and will be required to grant RCVS Knowledge a non-exclusive license of the rights of copyright in the materials including but not limited to the right to publish, re-

publish, transmit, sell, distribute and otherwise use the materials in all languages and all media throughout the world, and to license or permit others to do so.

\section{Disclaimer}

Knowledge Summaries are a peer-reviewed article type which aims to answer a clinical question based on the best available current evidence. It does not override the responsibility

of the practitioner. Informed decisions should be made by considering such factors as individual clinical expertise and judgement along with patient's circumstances and owners' values. Knowledge Summaries are a resource to help inform and any opinions expressed within the Knowledge Summaries are the author's own and do not necessarily reflect the view of the RCVS Knowledge. Authors are responsible for the accuracy of the content. While the

Editor and Publisher believe that all content herein are in accord with current recommendations and practice at the time of publication, they accept no legal responsibility

for any errors or omissions, and make no warranty, express or implied, with respect to material contained within.

For further information please refer to our Terms of Use.

RCVS Knowledge is the independent charity associated with the Royal College of Veterinary Surgeons (RCVS). Our ambition is to become a global intermediary for evidence based veterinary knowledge by providing access to information

that is of immediate value to practicing veterinary professionals and directly contributes to evidence based clinical decision-making.

https://www.veterinaryevidence.org/

RCVS Knowledge is a registered Charity No. 230886.

Registered as a Company limited by guarantee in England and Wales No. 598443.

Registered Office: Belgravia House, 62-64 Horseferry Road, London SW1P 2AF

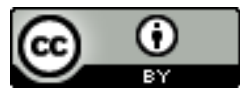

This work is licensed under a Creative Commons Attribution 4.0 International License. 